\title{
Krill transport in the Scotia Sea and environs
}

\author{
EILEEN E. HOFMANN ${ }^{1}$, JOHN M. KLINCK ${ }^{1}$, RICARDO A. LOCARNINI' ${ }^{1}$, BETTINA FACH ${ }^{1}$ \\ and EUGENE MURPHY²
}

\author{
${ }^{\prime}$ Center for Coastal Physical Oceanography, Crittenton Hall, Old Dominion University, Norfolk, VA 23529, USA \\ ${ }^{2}$ British Antarctic Survey, Natural Environment Research Council, High Cross, Madingley Road, Cambridge CB3 OET, UK
}

\begin{abstract}
Historical observations of the large-scale flow and frontal structure of the Antarctic Circumpolar Current in the Scotia Sea region were combined with the wind-induced surface Ekman transport to produce a composite flow field. This was used with a Lagrangian model to investigate transport of Antarctic krill. Particle displacements from known krill spawning areas that result from surface Ekman drift, a composite large-scale flow, and the combination of the two were calculated. Surface Ekman drift alone only transports particles a few kilometres over the 150-day krill larval development time. The large-scale composite flow moves particles several hundreds of kilometres over the same time, suggesting this is the primary transport mechanism. An important contribution of the surface Ekman drift on particles released along the continental shelf break west of the Antarctic Peninsula is moving them north-northeast into the high-speed core of the southern Antarctic Circumpolar Current Front, which then transports the particles to South Georgia in about 140-160 days. Similar particle displacement calculations using surface flow fields obtained from the Fine Resolution Antarctic Model do not show overall transport from the Antarctic Peninsula to South Georgia due to the inaccurate position of the southern Antarctic Circumpolar Current Front in the simulated circulation fields. The particle transit times obtained with the composite large-scale flow field are consistent with regional abundances of larval krill developmental stages collected in the Scotia Sea. These results strongly suggest that krill populations west of the Antarctic Peninsula provide the source for the krill populations found around South Georgia.
\end{abstract}

Received 23 December 1997, accepted 13 July 1998

Key words: Antarctic Circumpolar Current, Antarctic krill transport, Lagrangian models, South Georgia

\section{Introduction}

The Scotia Sea is located in the south-western Atlantic sector of the Southern Ocean (Fig. 1). It is bounded along its northern, eastern, and southern sides by the North Scotia Ridge, the South Sandwich Arc, and the South Scotia Ridge, respectively, and it opens to Drake Passage to the west. It is in the Scotia Sea where two important components of the Southern Ocean circulation meet: the Antarctic Circumpolar Current and the Weddell Gyre (Deacon \& Moorey 1975).

The Scotia Sea and environs have long been known to be one of the most biologically-rich areas of the Southern Ocean. In fact, the discovery and first explorations of the region were accomplished mainly by whaling and sealing expeditions during the early 19th century (Fogg 1992). The results of the Discovery Investigations clearly illustrated that this region supports a large standing stock of Antarctic krill, Euphausia superba Dana (Marr 1962).

The large-scale circulation of the Scotia Sea consists of north-eastward flow in which are embedded regions of high speed that are associated with fronts. Figure 1 shows the three fronts and the southern boundary of the Antarctic Circumpolar Current (ACC) in the south-western Atlantic Ocean as determined by Orsi et al. (1995). The Subantarctic Front (SAF) and the Polar Front (PF) enter the Scotia Sea through Drake Passage and exit it to the north between $60^{\circ} \mathrm{W}$ and $50^{\circ} \mathrm{W}$ (Fig. 1). The SAF flows northward along the continental slope off South America up to about $40^{\circ} \mathrm{S}$ (not shown). Here, it turns back poleward to about $49^{\circ} \mathrm{S}$ and continues eastward next to the PF in the southern Argentine Basin, about $550 \mathrm{~km}$ north of South Georgia.

In southern Drake Passage, the southern ACCFront(SACCF) and the southern boundary of the $\mathrm{ACC}$ (Bndry) flow eastward very close to the edge of the continental shelf west of the Antarctic Peninsula (Fig. 1). In fact, recent hydrographic data collected in this region place these features $30 \mathrm{~km}$ poleward of the mean locations shown in Fig. 1, with the Bndry inshore of the 2000-m isobath (Smith et al. in press). In contrast to the $\mathrm{SAF}$ and the PF, the SACCF and the Bndry flow along the entire Scotia Sea. Leaving the Scotia Sea, the SACCF flows along the eastern and northern continental slope of South Georgia, before turning clockwise and continuing its eastward circumpolar path. Orsi et al. (1995) refer to the zone between the SACCF and the Bndry as the southern ACC.

East of the Antarctic Peninsula (about $55^{\circ} \mathrm{W}$ ), the Bndry moves equatorward away from the South Scotia Ridge (Fig. 1) and indicates the boundary between the ACC and the Weddell Gyre. Cold waters from the western continental shelf and slope of the Weddell Sea are injected into the Scotia Sea and flow eastward superimposed on the southern ACC and northern 


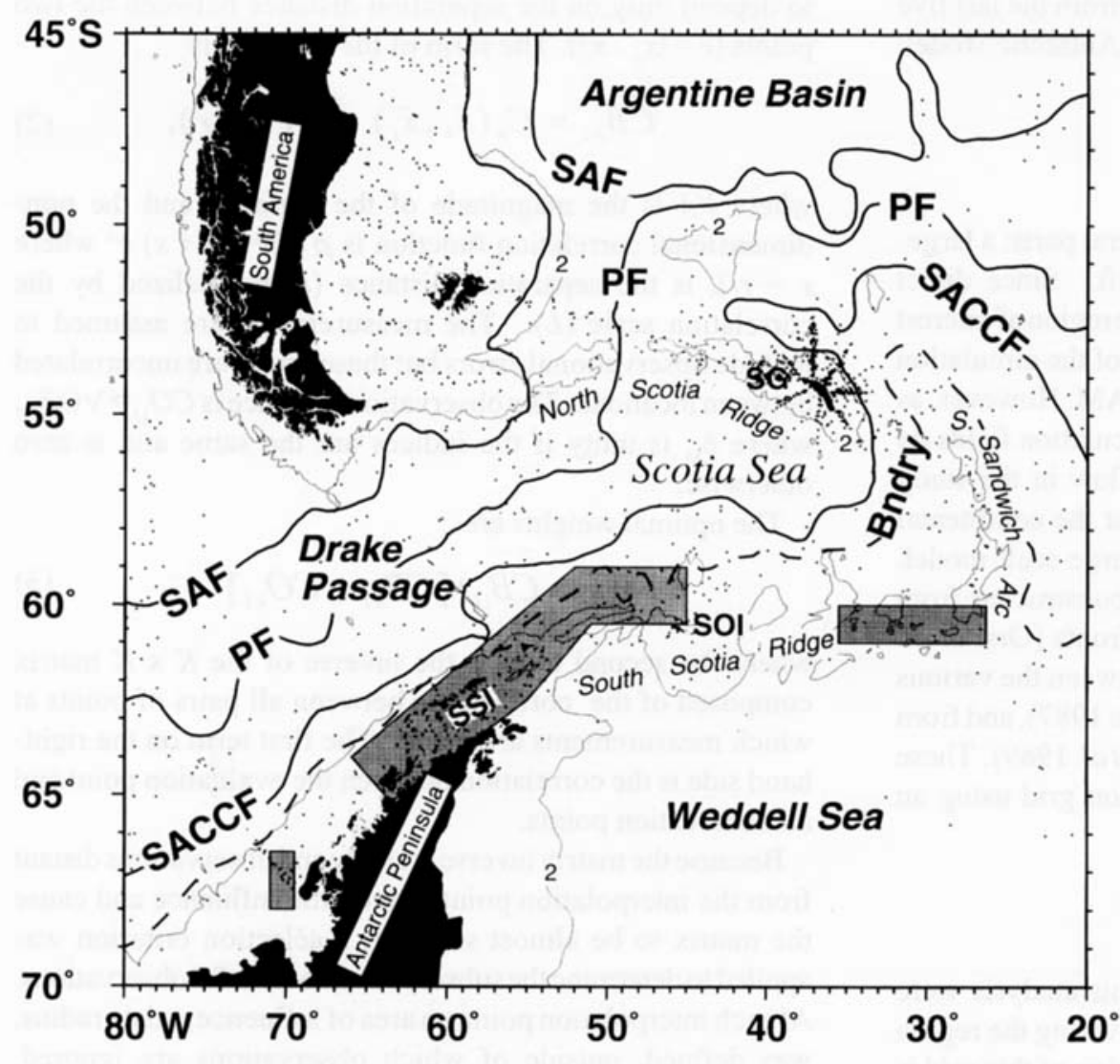

Fig. 1. Base map showing the study region, the location of the Subantarctic Front (SAF), the Polar Front (PF) and the southern ACC Front (SACCF), and southern boundary of the Antarctic Circumpolar Current (dashed line; Bndry). The front locations were determined by Orsi et al. (1995) from historical hydrographic data. The thin line represents the $2000-\mathrm{m}$ isobath. The dots indicate the stations occupied during the Discovery Investigations. The shading indicates regions where Euphausia superba eggs were observed in samples taken during the Discovery Investigations (see fig. 65 in Marr 1962). Geographic names are abbreviated as South Georgia (SG), South Orkney Islands (SOI), and South Shetland Islands (SSI).
Weddell Gyre systems (Whitworth et al. 1994). The region identified by mixtures of waters from these three regimes is known as the Weddell-Scotia Confluence (WSC). Although the northern boundary of the WSC may coincide at different times and locations with either the SACCF or the Bndry, they all are, by definition, independent and distinct features. The WSC is a local and peculiar hydrographic zone with flows and volume transports that are not well defined. The SACCF and Bndry are the major circumpolar deep-ocean fronts south of the Polar Front, and have associated with them strong current flows. Although the influence of the WSC hydrographic characteristics on the biological properties of the southern Scotia Sea cannot be disregarded, this study will show that the main link between the western Antarctic Peninsula and South Georgia are the dynamic features of the southern ACC.

The waters on the continental shelf and slope around South Georgia support a varied and rich fauna (Hardy \& Gunther 1935) and are characterized by large populations of krill, marine mammals, and seabirds (e.g., Croxall et al. 1988, Fedoulov et al. 1996, Murphy et al. 1997). Many of these species are dependent upon Antarctic krill as food during some or all of their life history. However, breeding populations of Antarctic krill have not been observed in the region around South Georgia (Everson 1984). It has been suggested that the population of Antarctic krill around South Georgia is supplied from breeding populations located upstream (Everson 1977) and that the structure of the ACC and its associated fronts are the primary factors determining the delivery of these krill to South Georgia (Priddle et al. 1988, Witek et al. 1988).

The krill egg distribution in January and February, which coincides with peak krill spawning, obtained from the Discovery Investigations (Fig. 1) provides support for the spatial separation of breeding krill populations from those around South Georgia. Krill eggs were found along the west Antarctic Peninsula and to the east towards the South Orkney Islands. No krill eggs were found around South Georgia. The extensive spatial coverage of the Discovery Investigations between $50^{\circ}-65^{\circ} \mathrm{S}$ shows that this pattern is representative of actual conditions and not the result of sampling bias. Also, limited-area drifter studies (Ichii \& Naganobu 1996), correlation studies of environmental variability and South Georgia krill populations (Fedoulov et al. 1996) and theoretical modeling efforts (Murphy 1995) suggest a connection between krill populations in the South Shetland and South Orkney Islands with those around South Georgia.

The objective of this paper is to use historical data on ACC flow and krill distributions to ascertain whether krill transported from the Antarctic Peninsula are the source for krill populations off South Georgia. The flow and krill data sets are combined in a Lagrangian particle tracking model which gives simulated trajectories that provide insight to potential transport pathways. For comparison, similar Lagrangian calculations were done 
with the mean surface flow field calculated from the last five years of simulation with the Fine Resolution Antarctic Model, FRAM (Webb et al. 1991).

\section{Data and methods}

Near-surface flow is composed of two general parts: a largescale flow and a wind-driven Ekman drift. Since direct measurements of surface flow throughout the region of interest (Fig. 1) do not exist, the next best estimate of the circulation is that from a dynamical model, such as FRAM. However, as will be shown later, the FRAM-derived circulation fields do not correctly represent the details of the flow in the study region at the scale of fronts, especially near the continental shelf break which is poorly resolved in this large-scale model.

The flow in the region of interest was constructed from historical observations of the location of fronts (Orsi et al. 1995), the estimate of flow speed in and between the various fronts (Hofmann 1985, Whitworth \& Nowlin 1987), and from estimates of surface wind stress (Trenberth et al. 1989). These various data were interpolated to a common grid using an optimal interpolation technique.

\section{Optimal interpolation approach}

The wind stress and flow fields used in this analysis were interpolated onto a regular grid of points covering the region from $70^{\circ}-45^{\circ} \mathrm{S}$ and $80^{\circ}-20^{\circ} \mathrm{W}$. The resolution of this grid is $0.1^{\circ}$ in latitude and $0.2^{\circ}$ in longitude, giving a spatial resolution of $c .10 \mathrm{~km}$ in each direction, which is adequate to represent the flow structure associated with the fronts. A land mask was defined for this grid so that flow is zero at land points.

Optimal interpolation $(\mathrm{OI})$ was used to interpolate the wind stress and flow values onto the standard grid (Bretherton et al. 1976, Daley 1991). The interpolation is optimal in the sense that it is an unbiased linear estimator of a quantity from a series of measurements that minimizes the variance of the estimate.

For a set of measurements of a quantity, $A$, at locations, $x_{k}$ which is denoted by $A O_{k}$, the optimal estimate of $A$ at a set of points, $\boldsymbol{x}_{i}$, is obtained from measurements as:

$$
A_{i}=A B_{i}+\sum_{k=1}^{K} W_{i k}\left(A B_{k}-A O_{k}\right) \text {, }
$$

where $A B$ is the background value or climatology of variable $A$ and $W$ is a set of weights that results in the optimal estimate. The climatology is known at the observation points $\left(A B_{k}\right)$ and the estimation $(A B)$ points. The OI uses the difference between the measurement and the climatology, thereby incorporating the new information included in the measurements into the estimated field of the variable of interest.

The weight, $W$, is determined from known statistical properties of the background values and measurements. The correlation between measurements at two locations is assumed to depend only on the separation distance between the two points $\left(r=\left|x_{k}-x_{i}\right|\right)$. The form of the function is:

$$
C B_{k l}=C_{b}\left(\vec{x}_{k}, \vec{x}_{l}\right)=V A * \rho(r),
$$

where $V A$ is the magnitude of the variance and the nondimensional correlation function is $\rho(s)=(I+s) e^{-s}$ where $s=r / L$ is the separation distance $(r)$ normalized by the correlation scale $(L)$. The measurements are assumed to include observational errors but these errors are uncorrelated between locations. The observation variance is $C O_{k l}=\operatorname{VO} \delta_{k l}$, where $\delta_{k l}$, is unity if the indices are the same and is zero otherwise.

The optimal weights are:

$$
W_{i k}=C B_{i l} *\left[C B_{k l}+C O_{k l}\right]^{-1},
$$

where the second term is the inverse of the $K \times K$ matrix composed of the correlations between all pairs of points at which measurements are made. The first term on the righthand side is the correlation between the evaluation point and all observation points.

Because the matrix inverse is costly and observations distant from the interpolation points have little influence and cause the matrix to be almost singular, a selection criterion was applied to determine the subset of the most useful observations. At each interpolation point, an area of influence, a data radius, was defined, outside of which observations are ignored. Parameter choices for interpolation for the variables used in this study are given in Table $\mathrm{I}$.

\section{Surface Ekman drift}

The Ekman drift was calculated from the surface wind stress ( $\tau$ ) extracted from the Trenberth et al. (1989) climatology for the month of January. Recent analyses (Chelton et al. 1990) indicate that the Trenberth et al. (1989) climatology is more representative of the wind stress for the Southern Ocean than other climatologies (e.g., Hellerman \& Rosenstein 1983).

The wind stress (dynes $\mathrm{cm}^{-2}$ ) was interpolated from the original $2.5^{\circ}$ by $2.5^{\circ}$ grid to the base grid using the interpolation parameters given in Table I. The average flow driven by the surface wind stress was obtained on the base grid from:

$$
\left(U_{E}, V_{E}\right)=\frac{\left(\tau^{y},-\tau^{x}\right)}{\rho_{o} f H},
$$

where $\left(U_{E}, V_{E}\right)$ is the depth-averaged Ekman drift in the surface layer, $\rho_{0}=1028 \mathrm{~kg} \mathrm{~m}^{-3}$ is the water density, $f=1.459$, $\sin$ (latitude) $\times 10^{-4} \mathrm{~s}^{-1}$, and $H=100 \mathrm{~m}$ is the depth of the surface layer.

The resultant surface flow (Fig. 2a) shows relatively weak velocities, less than $0.02 \mathrm{~m} \mathrm{~s}^{-1}$, over the study region. The general direction of the surface Ekman drift is to the NNE, which is consistent with the large-scale wind patterns for this region. 
Table 1. Parameters used for the optimal interpolation of flow and wind stress onto the base grid.

\begin{tabular}{lcccc}
\hline Variable & $\begin{array}{c}\text { Decay scale } \\
(\mathrm{km})\end{array}$ & $\begin{array}{c}\text { Variance } \\
\left(\mathrm{m}^{2} \mathrm{~s}^{-2}\right)\end{array}$ & $\begin{array}{c}\text { Obs. error } \\
\left(\mathrm{m}^{2} \mathrm{~s}^{-2}\right)\end{array}$ & $\begin{array}{c}\text { Data radius } \\
\left({ }^{\circ}\right)\end{array}$ \\
\hline flow climatology & 300 & 0.01 & 0.0025 & 5.0 \\
flow features & 10 & 0.01 & 0.0025 & 1.5 \\
wind stress & 300 & 1.0 & 0.1 & 2.5 \\
\hline
\end{tabular}

\section{Large-scale surface circulation}

The large-scale flow climatology was created from flow values defined on a $5^{\circ}$ by $5^{\circ}$ grid. About 10 additional points were added to this grid, primarily in central Drake Passage, to better specify the broad-scale flow. The flow direction at each point on this grid was determined from the frontal positions (Fig. 1), and the flow speed was taken from the surface drifter analysis of Hofmann (1985) and from geostrophic calculations by Whitworth \& Nowlin (1987). The coarse scale flows were then interpolated onto the base grid using the characteristic parameters given in Table I. The resultant flow (Fig. 2b) shows the general east-north-eastward flow that is associated with the ACC in the Drake Passage and Scotia Sea.

The frontal jets were then added to the large-scalecirculation with a feature model. In this approach, the fronts were represented as Gaussian jets along a straight line in a background flow that may differ on either side of the jet. The whole frontal jet was defined piecewise by line segments along the location of the front. Each line segment was defined by a pair of points specified by latitude and longitude. A local coordinate system was defined with $\mathrm{x}^{\prime}$ along the segment in the direction of flow and $y^{\prime}$ normal to the line according to the right hand rule. A set of points was defined in the local coordinate system with a spacing of $10 \mathrm{~km}$, extending the length of the line segment and extending three decay scales (defined later) to either side of the line.

Within the local grid, the flow speed was calculated according to the model:

$$
\begin{aligned}
& V=V_{\text {len }}(1-w)+w, V_{\text {jet }} \text { for } y^{\prime}>0 \\
& V=V_{\text {right }}(1-w)+w, V_{\text {jet }} \text { for } y^{\prime}<0,
\end{aligned}
$$

where $w=e^{\left(-y^{12} / 2 L_{p}^{2}\right)}$, defines the structure of the jet and $L_{y}$ is the width scale of the jet. The parameters $V_{\text {lef }}, V_{\text {jet, }}$, and $V_{\text {right }}$ define the flow speed in and on either side of the jet. The feature model provides the flow vectors at a set of points that are sufficient to represent the structure of the jet. These values are used by the optimal interpolation to create a flow for every point in the grid. Four jets were included in the analysis (SAF, PF, SACCF and Bndry, Fig. 1) using the parameter choices in Table II.

\section{Composite flow field}

The composite flow field produced by combining the surface Ekman drift, large-scale background flow and the frontal jets
(Fig. 3a) is consistent with what is known about the large-scale structure of the Antarctic CircumpolarCurrent and the northern Weddell Gyre in the region (Nowlin \& Clifford 1982, Orsi et al. 1993, Orsi et al. 1995). The general transport is to the ENE. Velocities associated with the frontal regions in northern Drake Passage are stronger than those in the southern Passage. The northward deflection of the SAF and PF as they exit Drake
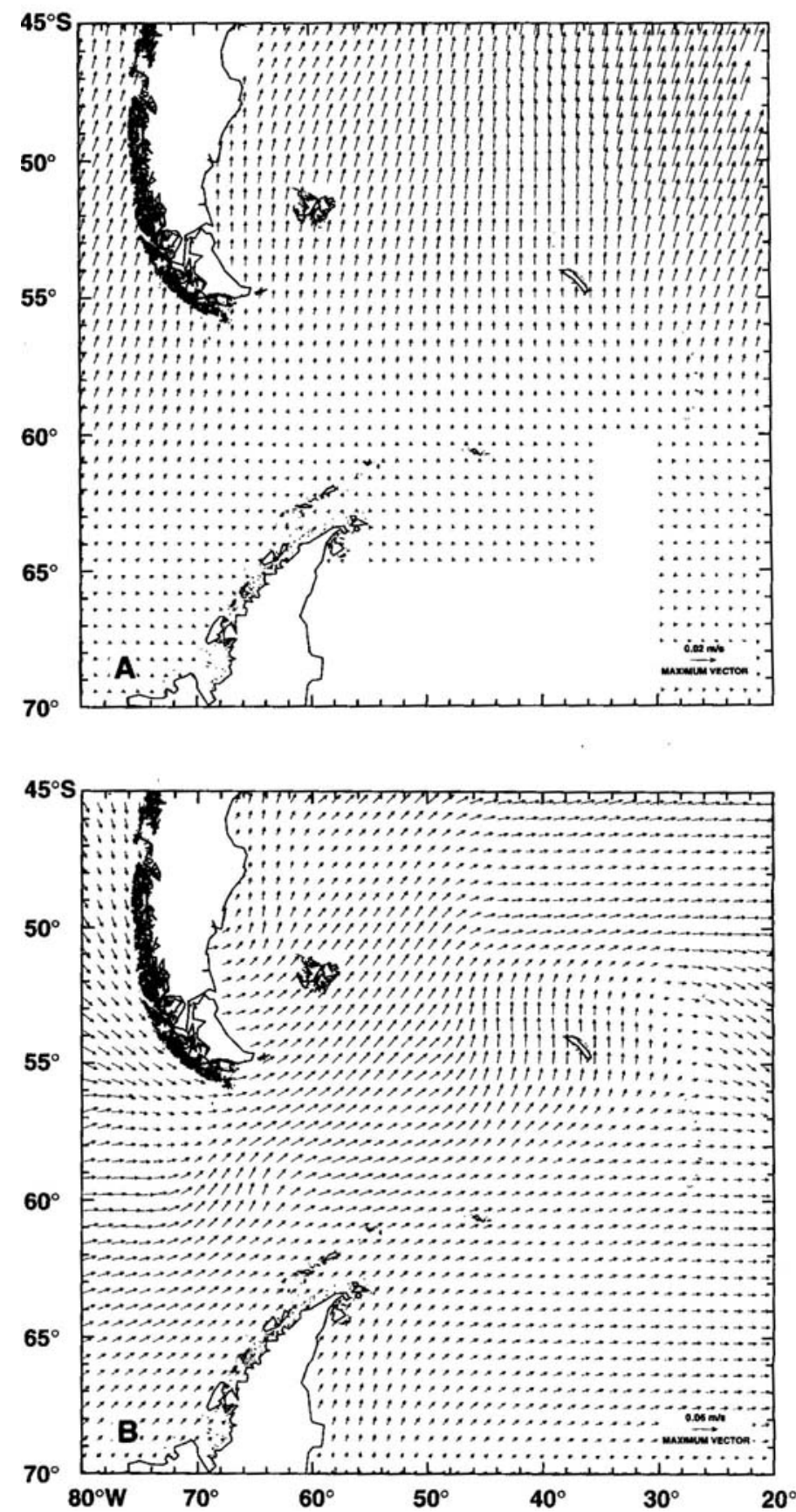

Fig. 2. a. Surface Ekman flow calculated from the Trenberth et al. (1989) wind stress climatology for January. The blank regions indicate areas where wind values were missing or areas where the calculated surface Ekman flow was less than $0.1 \mathrm{~mm} \mathrm{~s}^{-1}$. b. Large-scale background flow climatology. 
Table II. Parameters used to create the frontal jets.

\begin{tabular}{lcccc}
\hline Front & $\begin{array}{c}V_{\text {lefi }} \\
\left(\mathrm{m} \mathrm{s}^{-1}\right)\end{array}$ & $\begin{array}{c}V_{\text {jet }} \\
\left(\mathrm{m} \mathrm{s}^{-1}\right)\end{array}$ & $\begin{array}{c}V_{\text {rigki }} \\
\left(\mathrm{m} \mathrm{s}^{-1}\right)\end{array}$ & $\begin{array}{c}\text { Scale } \\
(\mathrm{km})\end{array}$ \\
\hline Bndry & 0.05 & 0.10 & 0.10 & 20 \\
southern ACC & 0.29 & 0.30 & 0.05 & 20 \\
polar & 0.35 & 0.40 & 0.29 & 30 \\
subantarctic & 0.28 & 0.44 & 0.35 & 30 \\
\hline
\end{tabular}
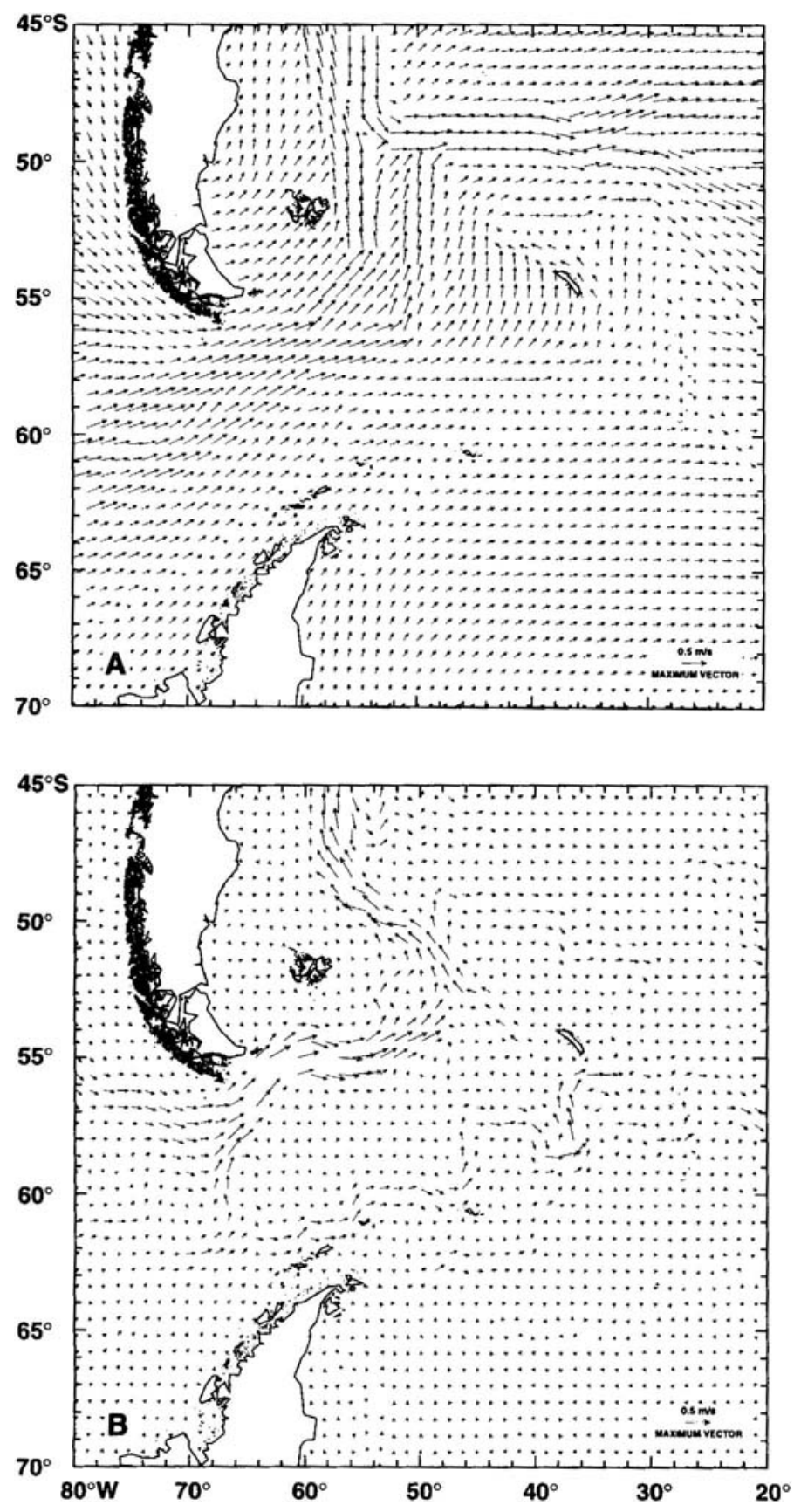

Fig. 3. a. Large-scale composite flow constructed from combining the background flow climatology, the surface Ekman flow, and front speeds and locations. b. Large-scale surface flow calculated from the mean of the last five years of simulation from FRAM.
Passage is apparent, as is the deflection of the SAACF around South Georgia. Flow from the Weddell Sea is primarily to the NNE.

\section{FRAM circulation field}

The surface circulation obtained from averaging the last five years of the FRAM simulation (Fig. 3b) shows the same general ENE pattern as seen in the composite flow field. However, the two flow representations differ in the details, especially in regard to the location of the fronts associated with the ACC. In the FRAM simulation the SACCF forms from a bifurcation of the PF as it enters Drake Passage (Gross et al. 1995). The northern branch of this flow turns NNE as it exits Drake Passage and flows along the coast of South America. The southern branch flows along the Antarctic Peninsula and continues eastward across the Scotia Sea after exiting Drake Passage. Thus, the SACCF in Drake Passage is formed from (or merges with) the PF and these flow features appear as one jet to the west of Drake Passage (Gross et al. 1995).

\section{Lagrangian model}

The trajectory followed by a particle is calculated from:

$$
\frac{d \vec{X}}{d t}=\vec{U}(\vec{X}, t),
$$

where $X$ is the particle location at time, $t$, and $U(X, t)$ is the water velocity. For this study, $\boldsymbol{U}(\boldsymbol{X}, t)$ is composed of the Ekman and large-scale flows, obtained as described in the previous section. In this study, the Ekman and large-scale flows are time invariant.

Several particles were released in the flow field and tracked over time. The particle release point coincided with regions in which eggs of Antarctic krill have been observed (Fig. 1). This assumes that krill eggs represent regions in which reproductive and spawning Antarctic krill populations are found. After release, the particle trajectories were calculated for displacements due to the Ekman wind drift, the large-scale flow, and the combined Ekman and large-scale flows. Particle locations were calculated using a second-order Runge-Kutta numerical integration scheme (Press et al. 1986).

\section{Results \\ Wind-induced transport}

The embryos of Antarctic krill are within the upper $100-150 \mathrm{~m}$ for part of their development and, after metamorphosis to the first feeding stage, krill larvae remain in the surface waters (Hofmann et al. 1992). The older larval forms of Antarctic krill are also found in the upper water column. Consequently, wind-induced surface currents are potentially important in the 
transport of krill larvae. Therefore, the first set of particle trajectory calculations considered displacement due only to surface Ekman drift.

The particle displacement due to wind-induced surface flow was towards the NNE, but with distances less than $10 \mathrm{~km}$ over 30 days (Table III). Errors in the estimates of the surface wind stress have a negligible effect on the particle trajectories. An error in the stress of $0.1 \mathrm{~N} \mathrm{~m}^{-2}$ (about $100 \%$ error) produces a change in the Ekman speed of $0.00075 \mathrm{~m} \mathrm{~s}^{-1}$ which results in a displacement error over 150 days of about $10 \mathrm{~km}$. While such deflections can move a particle in or out of a high-speed current, these small differences can be ignored for the calculations presented here.

\section{Wind-induced and large-scale flow transport}

The particle displacement that results from large-scale flow is much greater than that produced by only wind-induced flow (Table IV). The total displacement over 30 days is in excess of $250 \mathrm{~km}$ for some particles, with daily displacements of almost $20 \mathrm{~km}$. The general transport direction for particles released in the krill egg regions is ENE.

The trajectories show that particles released to the west of the Antarctic Peninsula are transported by the SACCF and reach South Georgia in 140-160 days (Fig. 4). To the east of the Antarctic Peninsula, particles released east of $40^{\circ} \mathrm{W}$ move to the east with the flow of the Weddell Gyre. However, particles released near the tip of the Antarctic Peninsula move NNE, where they become entrained in the SACCF and are transported to South Georgia.

Errors in the particle drift estimates occur due to error in the estimates of surface speed and errors in the direction of surface speed. The surface flow speed, taken from surface drifters (Table II), ranges from 0.3 to $0.45 \mathrm{~m} \mathrm{~s}^{-1}$. With a drift time of 150 days, this velocity range allows a particle to move $389-583 \mathrm{~km}$. If the surface speeds are in error by as much as $0.1 \mathrm{~m} \mathrm{~s}^{-1}$, then a particle would have a displacement error over 150 days of $130 \mathrm{~km}$. However, faster or slower speeds will change this displacement error accordingly.

An error in the direction of the surface speed of $10^{\circ}$ over the whole length of the particle trajectory, produces a transverse deflection of 68 to $101 \mathrm{~km}$ for flow speeds of 0.3 and

Table III. Particle displacement characteristics over 30 days due to Ekman flow.

\begin{tabular}{|c|c|c|c|c|c|}
\hline \multicolumn{2}{|c|}{ Initial location } & \multicolumn{2}{|c|}{ Displacement } & \multirow[b]{2}{*}{$\begin{array}{l}\text { heading } \\
\text { ( }{ }^{\circ} \text { true) }\end{array}$} & \multirow[b]{2}{*}{$\begin{array}{c}\text { speed } \\
\left(\mathrm{km} \mathrm{d}^{-1}\right)\end{array}$} \\
\hline $\begin{array}{l}\text { latitude } \\
\left({ }^{\circ} \mathrm{S}\right)\end{array}$ & $\begin{array}{c}\text { longitude } \\
\left({ }^{\circ} \mathrm{W}\right)\end{array}$ & $\begin{array}{l}\text { east } \\
(\mathrm{km})\end{array}$ & $\begin{array}{l}\text { north } \\
(\mathrm{km})\end{array}$ & & \\
\hline 62.988 & 63.281 & 4.40 & 2.80 & 57 & 0.17 \\
\hline 64.211 & 66.258 & 6.60 & 1.10 & 80 & 0.22 \\
\hline 65.623 & 68.899 & 6.90 & -0.60 & 95 & 0.23 \\
\hline 66.848 & 72.142 & 7.15 & -3.90 & 119 & 0.27 \\
\hline 61.000 & 55.000 & -0.35 & 6.60 & -3 & 0.22 \\
\hline
\end{tabular}

$0.45 \mathrm{~m} \mathrm{~s}^{-1}$, respectively. These errors, over the path from the Antarctic Peninsula to South Georgia, are about the size of the island making the errors potentially important. However, both error estimates are extreme choices and as such they produce negligible to moderate changes in the estimated drift path; they do not change the basic results of the particle displacement experiments.

\section{FRAM transport}

The trajectories of particles released west of the Antarctic Peninsula in the FRAM-derived surface circulation fields (Fig. 5) show considerable north-south meandering, but the general transport is to the east. All particles pass to the south of South Georgia, except for one that moves northward to $50^{\circ} \mathrm{S}$ and then eastward. In this simulation none of the particles arrive at South Georgia.

\section{Discussion and summary}

The wind-induced surface transport was insufficient to move particles more than a few kilometres from their release site over 30 days (Table III). Displacements of several hundred kilometres occurred only when particles were entrained in the currents associated with the fronts in the ACC system. However, the effect of the wind-induced transport is not to be discounted as unimportant. The small NNE Ekman drift of particles released west of the Antarctic Peninsula and those released near the tip of the Peninsula is sufficient to move these particles into the high-speed core of the SACCF where they are transported to the NNE by the SACCF, reaching South Georgia in 140-160 days. Thus, the combined effect of the Ekman and large-scale flow (Fig. 4) allows particles to be entrained in the SACCF and be transported to South Georgia.

The simulated particle trajectories strongly suggest that krill populations west of the Antarctic Peninsula provide the source for the populations found around South Georgia. The development and growth of Antarctic krill is such that it should develop to a length of $10-12 \mathrm{~mm}$ in $140-160$ days, assuming spawning in mid-summer (see review in Quetin et al. 1994). Thus, the transport directions and transit times obtained from the Lagrangian model are such that krill spawned
Table IV. Particle displacement characteristics over 30 days due to the combined effects of Ekman and large-scale flow.

\begin{tabular}{cccccc}
\hline \multicolumn{2}{c}{ Initial location } & \multicolumn{3}{c}{ Displacement } \\
$\begin{array}{c}\text { latitude } \\
\text { longitude } \\
\left({ }^{\circ} \mathrm{S}\right)\end{array}$ & $\left({ }^{\circ} \mathrm{W}\right)$ & $\begin{array}{c}\text { east } \\
(\mathrm{km})\end{array}$ & $\begin{array}{c}\text { north } \\
(\mathrm{km})\end{array}$ & $\begin{array}{c}\text { heading } \\
\left({ }^{\circ} \text { true }\right)\end{array}$ & $\begin{array}{c}\text { speed } \\
\left(\mathrm{km} \mathrm{d}^{\circ}\right)\end{array}$ \\
\hline 62.988 & 63.281 & 191.9 & 123.5 & 57 & 7.6 \\
64.211 & 66.258 & 247.5 & 174.5 & 55 & 10.1 \\
65.623 & 68.899 & 340.9 & 262.6 & 52 & 14.3 \\
66.848 & 72.142 & 357.1 & 283.2 & 52 & 15.2 \\
61.000 & 55.000 & 473.3 & 210.0 & 66 & 17.3 \\
\hline
\end{tabular}



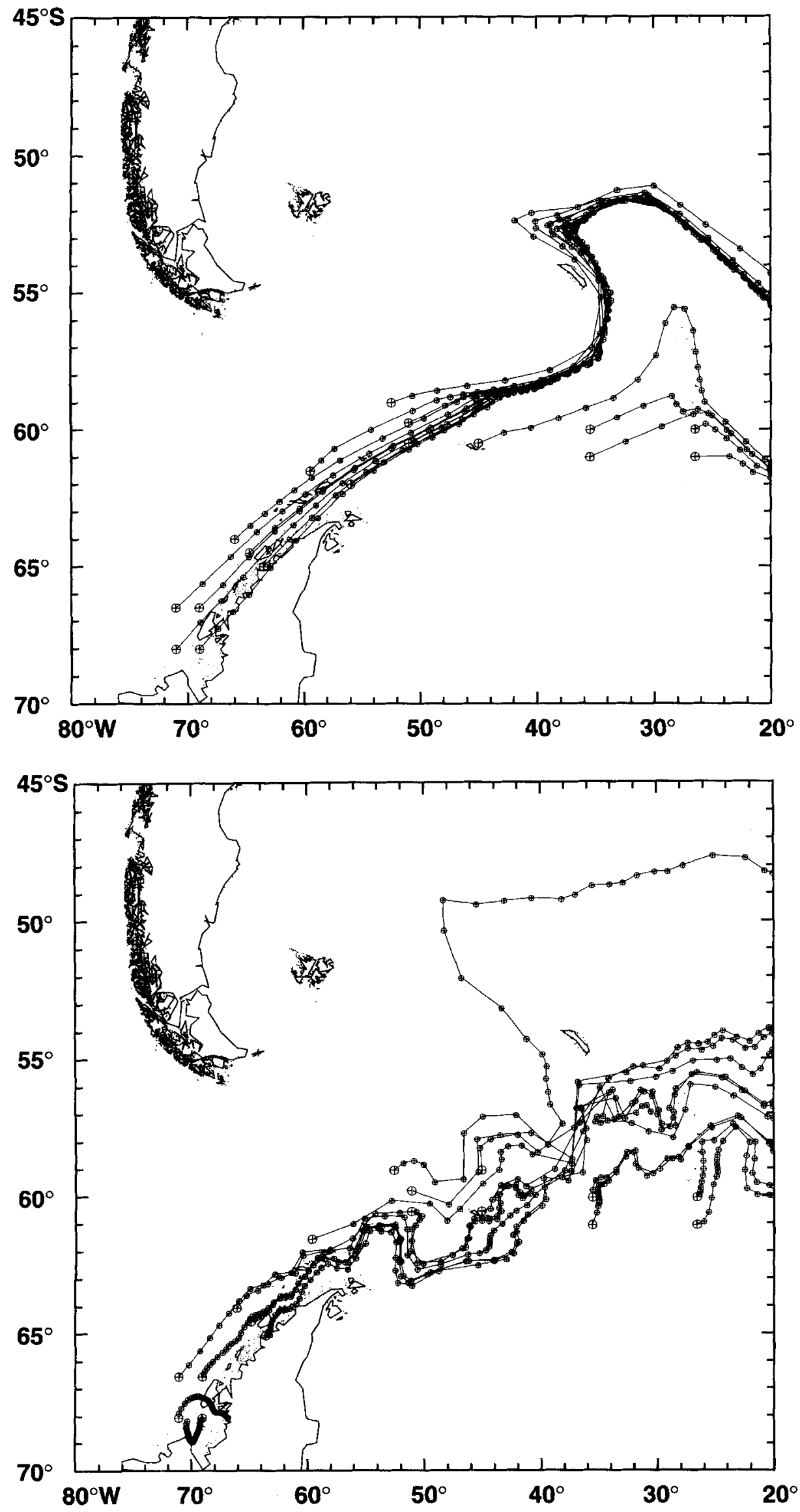

Fig. 4. Particle displacements obtained using the large-scale composite flow field. The symbols indicate the particle location at 10-day intervals. Particle release points correspond to the shaded regions shown in Fig. 1.
Fig. 5. Particle displacements obtained using the mean surface flow field from FRAM. The symbols indicate the particle location at 10-day intervals. Particle release points correspond to the shaded regions shown in Fig. 1. 
west of the Antarctic Peninsula will arrive at South Georgia as they are developing into the older juvenile stages. Ichii \& Naganobu (1996) found that drogued buoys drifted from the South Shetland Islands to South Georgia in $c$. 110-120 days, which is consistent with the simulated particle transit times.

Additional evidence for the transport of krill from the western side of the Antarctic Peninsula to South Georgia is given by the surface distribution of krill larvae (Fig. 6a). Surface larval abundances to the south of South Georgia tend to be low (1-10 individuals); whereas, those to the north of the island are higher (100-1000 individuals). Surface larval concentrations near the Antarctic Peninsula tend to be higher, but the overall distribution is not extensive. The major concentrations of surface larvae are associated with the historical locations of the SACCF and Bndry as these fronts extend across the Scotia Sea (Fig. 6a). With the exception of the larval concentrations in the Weddell Sea, essentially all of the surface larvae are found along or between the SACCF and Bndry.

The distribution of older krill stages (Fig. 6b) shows that these animals are found primarily around South Georgia. Observations of older krill stages around the Antarctic Peninsula show a more sparse distribution with concentration found in only a few areas. The largest concentration of older krill stages is found to the north of South Georgia, in the region influenced by the SACCF andBndry. Again, with the exception of the Weddell Sea populations, the distribution of the older krill stages across the Scotia Sea matches the historical location of the SACCF and Bndry.

The patterns of the simulated particle trajectories are consistent with regional abundances of larval krill developmental stages collected in the Scotia Sea north of the South Orkney Islands and east of Elephant Island (Brinton \& Townsend 1984), which supported the hypothesis that many of the krill larvae in the Scotia Sea are not produced locally but are brought there by currents. These observations showed that, moving from west to east over about $200 \mathrm{~km}$, the krill larvae were in older developmental stages. Experimental measurements of krill growth (Fig. 7) indicate that larval krill reach an average size of about $10 \mathrm{~mm}$ in 140-160 days, which is in agreement with krill larval sizes observed around South Georgia. The development of the larger juvenile krill suggests that year one larvae at South Georgia could also have been transported from the Antarctic Peninsula region.

This study shows the importance of the SACCF and the southern portion of the $\mathrm{ACC}$ in providing the primary transport mechanism for krill populations from the Antarctic Peninsula to the waters around South Georgia. Therefore, understanding the structure and variability of this current system is of primary importance in any management strategy that is developed and implemented for Antarctic krill in the Atlantic sector of the Southern Ocean.

\section{Acknowledgements}

Support for this study was provided by the US National Science Foundation, Office of Polar Programs grant number OPP-9525806. Computer facilities and resources were provided by the Commonwealth Center for Coastal Physical Oceanography. We thankA.H. Orsi for providing the digitized locations of the ACC fronts and boundary shown in Fig. 1 and
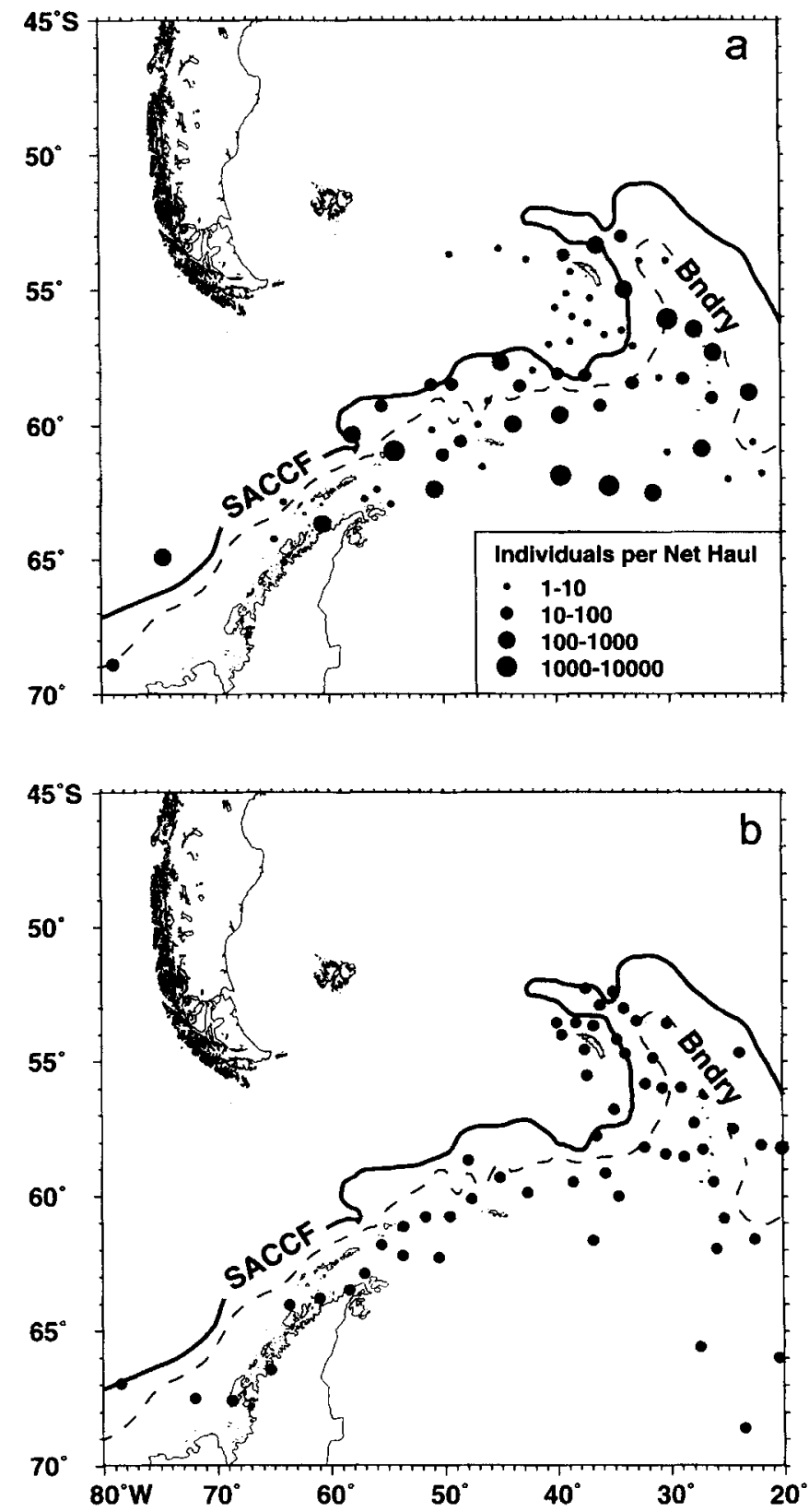

Fig. 6. a. Distribution and concentration of Euphausia superba larvae in the surface waters as given in Marr (1962).

b. Distribution of older Euphausia superba larvae as given in Marr (1962). The location of the southern ACC Front (SACCF) and southern boundary of the Antarctic Circumpolar Current (Bndry) are shown. 


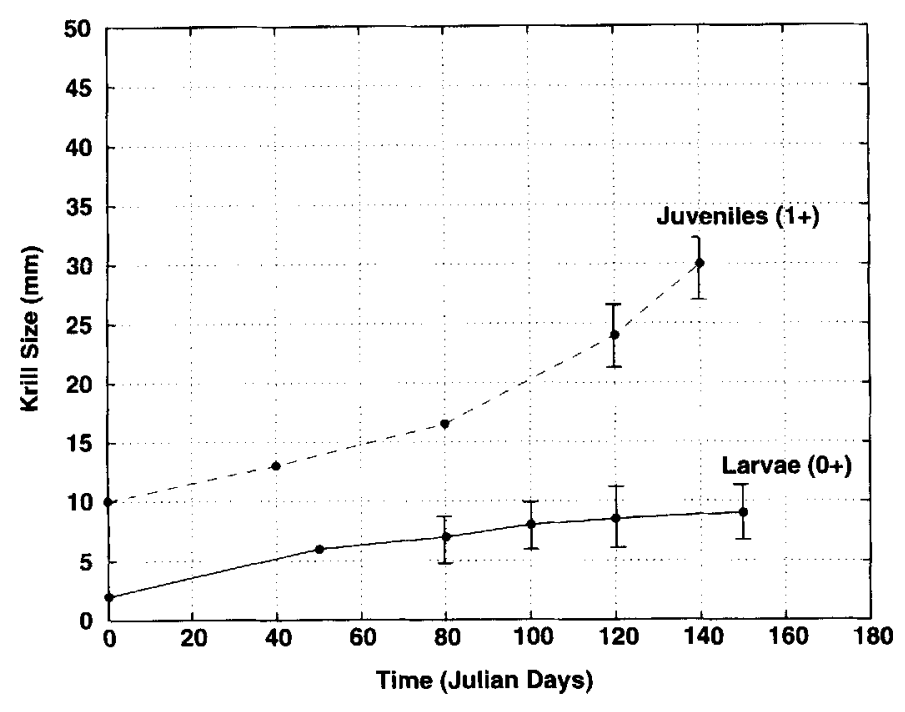

Fig. 7. Development time of Euphausia superba larvae and juveniles as determined from data in Siegel \& Kalinowski (1994) and Daly (1990).

the reviewers (V. Smetacek, V. Strass \& K.J. Heywood) and the editor for providing constructive comments on an earlier version of this paper.

\section{References}

Bretherton, F., Davis, R. \& Fandry, C. 1976. A technique for objective analysis and design of oceanographic experiments applied to MODE-73. Deep-Sea Research, 23, 559-592.

BRINTON, E.\& TOWNSEND, A.W. 1984. Regional relationships between development and growth in larvae of Antarctic krill, Euphausia superba from field samples. Journal of Crustacean Biology, 4, 224-246.

Chelton, D.B., Mestas-Nunez, A.M. \& Freilich, M.H. 1990. Global wind stress and Sverdurp circulation from the seasat scatterometer. Journal of Physical Oceanography, 20, 1175-1205.

Croxall, J.P., McCann, T.S., Prince, P.A. \& Rothery, P. 1988. Reproductive performance of seabirds and seals at South Georgia and Signy Isiand, South Orkney Islands, 1976-1987: implications for Southern Ocean monitoring studies. In Sahrhage, D., ed. Antarctic ocean and resources variability. Berlin: Springer-Verlag, 261-285.

DALY, K.L. 1990 . Overwintering development, growth and feeding of larval Euphausia superba in the Antarctic marginal ice zone. Limnology and Oceanography, 35, 1564-1576.

DALEY, R. 1991. Atmospheric data analysis. Cambridge: Cambridge University Press, $457 \mathrm{pp}$.

DeAcon, G.E.R. \& Moorey, J.A. 1975. The boundary region between currents from the Weddell Sea and Drake Passage. Deep-Sea Research, 22, 265-268.

EVERSON, I. 1977. The living resources of the Southern Ocean. GLO/ SO/77/1. Rome: Food and Agricultural Organization, $156 \mathrm{pp}$.

Everson, I. 1984. Marine interactions. In Laws, R.M., ed. Antarctic ecology, vol. 2. London: Academic Press, 783-819.

Fedoulov, P.P., MurPhy, E. \& Shulgovsky, K.E. 1996. Environmentkrill relations in the South Georgia marine ecosystem. CCAMLR Science, 3, 13-30.
FogG, G.E. 1992. A history of Antarctic science. Cambridge: Cambridge University Press, $483 \mathrm{pp}$.

Gross, T.J., Johnson, J.A. \& BIGG, G.R. 1995. A comparison between the FRAM (Fine Resolution Antarctic Model) results and observations in Drake Passage. Deep-Sea Research, 42, 365-388.

HARdy, A.C. \& GunTher, E.R. 1935. The plankton of the South Georgia whaling grounds and adjacent waters, 1926-1927.Discovery Reports, 11, 1-456.

Hellerman, S. \& Rosenstein, M. 1983. Normal monthly wind stress over the world ocean with error estimates. Journal of Physical Oceanography, 13, 1093-1104.

Hofmann, E.E. 1985. The large-scale structure of the Antarctic Circumpolar Current from FGGE drifters. Journal of Geophysical Research, 90, 7087-7097.

Hofmann, E.E., Capella, J.E., Ross, R.M. \& Quetin, L.B. 1992. Models of the early life history of Euphausia superba Part I. Time and temperature dependence during the descent-ascent cycle DeepSea Research, 39, 1177-1200.

ICHI, T. \& Naganobu, M. 1996. Surface water circulation in krill fishing areas near the South Shetland Islands. CCAMLR Science, $\mathbf{3}$, 125-136.

MARR, J. 1962. The natural history and geography of the Antarctic krill (Euphausia superba Dana). Discovery Reports, 32, 37-465.

MURPHY, E.J. 1995. Spatial structure of the Southern Ocean ecosystem: predator-prey linkages in Southern Ocean food-webs. Journal of Animal Ecology, 64, 333-347.

Murphy, E.J., Trathan, P.N., Everson, I., Parkes, G. \& Daunt, F. 1997. Krill fishing in the Scotia Sea in relation to bathymetry, including the detailed distribution around South Georgia. CCAMLR Science, 4, 1-17.

Nowlin JR, W.D. \& Clifford, M. 1982. The kinematic and thermohaline zonation of the Antarctic Circumpolar Current at Drake Passage. Journal of Marine Research, 40, 481-507.

Orsi, A.H., Nowlin JR, W.D. \& Whitworth III, T. 1993. On the circulation and stratification of the Weddcll Gyre. Deep-Sea Research, 40, 169-203.

Orsi, A.H., Whitworth III, T. \& Nowlin JR, W.D. 1995, On the meridional extent and fronts of the Antarctic Circumpolar Current. Deep-Sea Research, 42, 641-673.

Press, W.H., Flannery, B.P., Teukolsky, S.A. \& Vetterling, W.T. 1986. Numerical recipes. Cambridge: Cambridge University Press, $818 \mathrm{pp}$.

Priddle J., Croxall, J.P., Everson, I., Heywood, R.B., Murphy, E.J., Prince, P.A. \& SEAR, C.B. 1988. Large-scale fluctuations in distribution and abundance of krill-a discussion of possible causes. In SAHRHage, D., ed. Antarctic ocean and resources variability. Berlin: Springer-Verlag, 169-181.

Quetin, L.B., Ross, R.M. \& Clarke, A. 1994. Krill energetics: seasonal and environmental aspects of the physiology of Euphausia superba. In EL-SAYED, S.Z., ed. Southern Ocean ecology, the BIOMASS perspective. Cambridge: Cambridge University Press, 165-184.

Siegel, V. \& KALINOWSKI, J. 1994. Krill demography and small-scale processes: a review. In EL-SAYED, S.Z., ed. Southern ocean ecology, the BIOMASS perspective. Cambridge: Cambridge University Press, 145-163.

Smith, D.A., Hofmann, E.E., Klinck, J.M. \& Lascara, C.M. in press. Hydrography and circulation of the West Antarctic Peninsula continental shelf. Deep-Sea Research.

TRENBERTH, K.E., OLSON, J.G. \& LARGE, W.G. 1989. A global ocean wind stress climatology based on ECMWF analyses. NCAR Technical Note. NCAR/TN-338+STR, $93 \mathrm{pp}$.

WebB, D.I., Killworth, P.D., Coward, A.C. \& Thompson, S.R. 1991. The FRAM Atlas of the Southern Ocean. Swindon: Natural Environmental Research Council, 67 pp. 
WHITWORTH III, T.\& NoWLIN JR, W.D. 1987. Water masses and currents of the Southern Ocean at the Greenwich Meridian. Journal of Geophysical Research, 92, 6462-6476.

Whitworth I1I, T., Nowlin JR, W.D., ORSI, A.H., LoCARNini, R.A. \& SмIтH, S.G. 1994. Weddell Sea shelf water in the Bransfield Strait and Weddell-Scotia Confluence. Deep-Sea Research 41, 629-641.
Witek, Z., Kalinowski, J. \& GRelowski, A. 1988 . Formation of Antarctic krill concentrations in relation to hydrodynamic processes and social behavior. In SAHRHAGe, D., ed. Antarctic ocean and resources variability. Berlin: Springer-Verlag, 237-244. 